Lombard A, Grobbelaar $M$ \& Pruis $S$

\title{
STANDARDS FOR SOCIAL WORK QUALIFICATIONS IN SOUTH AFRICA
}

\author{
Antoinette Lombard, Margaret Grobbelaar and Santie Pruis ${ }^{1}$
}

\section{INTRODUCTION}

South Africa has instituted a new education and training dispensation, with the core drivers being the South African Qualifications Authority (SAQA), National Standards bodies and Education and Training Quality Assurance bodies (Olivier, 1998:ix). The SAQA Act (1995) enables South Africa to develop its own integrated National Qualifications Framework (NQF) accompanied by a supporting quality-assurance system.

SAQA's mission is to ensure the development and implementation of the NQF, which contributes to the full development of each learner and to the social and economic development of the nation at large. The NQF has been established to provide for the registration of national standards and qualifications.

According to SAQA's requirements, all qualifications and standards in South Africa must be formally registered by SAQA on the NQF by 30 June 2006. If qualifications have not been generated and approved by SAQA by this date, it means that neither providers nor learners' achievements will be recognised. The SAQA Act (1995) and its Regulations (1998a:17) make provision for the establishment of Standards Generating Bodies (SGBs) to develop standards and qualifications. For this purpose, an SGB for Social Work was established in order to generate standards and qualifications for Social Work, including Social Auxiliary Work.

All qualifications and standards must be approved by the National Standards Bodies (NSBs) and the South African Qualifications Authority. Social Work qualifications had to be approved by NSB 09: Health Sciences and Social Services. From its inception the SGB for Social Work had to submit progress reports to NSB 09 every second month. Although the NSB made a SAQA Coordinator available to the SGB for consultation purposes, the task and capacity building for the work of the SGB were very much a learning process, which unfolded as the development of the qualifications progressed.

Not only were the Social Work qualifications the first "whole qualifications" submitted to NSB 09 and SAQA, but Social Work was also the first of the health and social service professions in South Africa to submit its qualifications. The qualifications that have been approved for registration with the NQF by NSB 09 are the FET Certificate in Social Auxiliary Work, Bachelor of Social Work, Structured Master of Social Work, Research Master of Social Work and Doctor of Social Work.

1 Prof A Lombard is the Chairperson of the SGB; Chairperson of the SACSSP's Committee on Education and Training and Professor of Social Work at the University of Pretoria, South Africa.

Mrs M Grobbelaar is a member of the SGB, a member of NSB 09 and Co-ordinator of the National Coalition for Social Services (NACOSS), a coalition of national and provincial welfare organizations, Mrs S Pruis is a member of the SGB, a member of NSB 09 and the Manager: Education and Development of the SACSSP, Pretoria. South Africa.

It is acknowledge that the work of the SGB for Social Work is the result of a team effort. The 18 SGB members are therefore recognised for their dedicated and committed work. 
This article reports on SAQA's brief for SGBs; the process that was followed to establish an SGB for Social Work and write qualifications for Social Work; a brief outline of the contents of the Social Work qualifications; and the way forward after the qualifications have been registered on the NQF.

\section{SGB BRIEF}

An SGB is composed of key education and training stakeholders in the NSB sub-field, drawn from interest groups and specialists, as identified according to SAQA's requirements. Membership of SGBs does not exceed 25 members (SAQA Regulations, 1998a:19). The SGB for Social Work consists of interest groups, including educators and trainers, practitioners, NGOs, the South African Council for Social Service Professions (SACSSP), labour and critical interest groups such as Professional Associations. An SGB is registered for a 3-year period.

The number of gazetted members of the SGB for Social Work was 25 persons. As the process required members to devote considerable time to the SGB, a number of people resigned or were unable to participate. However, 18 members remained committed throughout the process, participating fully and enabling the SGB to complete the 5 qualifications.

The brief of the SGB for Social Work was as follows:

- Develop learning pathways for potential qualifications and unit standards in the area of Social Work from NQF Level 4 to Level 8;

- Generate qualifications and standards in the areas of Social Work in terms of the requirements of relevant legislation and the establishment of best practices;

- Recommend qualifications and standards to NSB 09;

- Recommend criteria for assessors and moderators/moderating bodies;

- $\quad$ Liaise with other NSBs and SGBs that have a vested interest in the subject;

- Perform such other functions as may from time to time be delegated by the NSB.

\section{SGB PROCESS}

\section{Application}

The initiative to investigate the launch of an SGB for Social Work started with an open invitation to all stakeholders in national newsletters in August 2000. The South African Council for Social Service Professions (SACSSP), in conjunction with the Joint Universities' Committee for Social Work (JUC), facilitated this process, which led to a workshop on 11 September 2000 attended by various stakeholders. The Workshop's objective was to start the process of consultation, negotiation and generation of support from key social work education and training stakeholders, interest groups and experts in order to get a mandate to apply for the establishment of an SGB for Social Work. An Interim Steering Committee was appointed to prepare the application to SAQA. Nominations for persons to serve on the SGB were called for in national newspapers in October 2000. Letters were also sent to numerous bodies and groups at national and provincial level in this regard. The final application was submitted to NSB 09 in December 2000.

The application to establish an SGB for Social Work was gazetted in the Government Gazette of 22 January 2001 for comments. After the required 30-day period, the SGB for Social Work was duly approved by SAQA on 24 March 2001 and registered on 12 April 2001 (SAQA, 2001:6). 


\section{MEETINGS}

The initial meeting of the SGB for Social Work was held in March 2001. The first challenge was to build the capacity of members and equip them for the task ahead. Initially, three orientation and capacity-building workshops were held with a consultant, after which the SGB continued on its own. Small task teams met regularly and took responsibility for specific drafting tasks and research. Up to the final submission of all the qualifications in December 2002 the SGB had held 12 plenary sessions, spread over two days per session. As indicated, numerous small task team meetings always preceded plenary sessions.

\section{FINANCING}

SAQA only makes financial provision for a once-off amount of R31 603 for the work of SGBs, which meant that the SGB had to seek its own avenues to access financing. Applications to the Health and Welfare Sector Education and Training Assurance Body (HWSETA) were successful in that an amount of R100 000 was granted for the 2001/02 financial year and a further grant of R150 000 was allocated for the year 2002/03.

The SGB also received significant support throughout the process from the SACSSP in the form of a venue, secretarial services and administrative support.

\section{Consultation with stakeholders}

From the start SAQA expected the SGB to consult with its constituencies and obtain feedback. The SGB was committed to upholding this principle and is convinced that it acted with the utmost transparency and consulted as far as possible with all stakeholders throughout the entire process.

The consultation process started in April 2001, when a wide range of stakeholders, specifically including employers and practitioners, was requested to submit recommendations regarding qualifications, based on the demands of social work practice in South Africa.

In addition, providers from higher tertiary institutions were requested to submit to the SGB the qualifications they had previously submitted to SAQA for interim registration. The recommendations and the contents of these qualifications were carefully considered, debated and utilised as guidelines, where appropriate, to draft the five social work qualifications.

In June 2002 the first draft of the FET Certificate in Social Auxiliary Work and the B SW qualifications on NQF Levels 4 and 7, respectively, were distributed to all stakeholders. These were followed in August 2002 by the draft Masters (NQF Level 8) and Doctoral (NQF Level 8+) qualifications. Stakeholders included the South African Council for Social Service Professions, employers (NGOs and public sector) professional associations, other social service professions and labour. Every single comment received was considered by the SGB; the necessary adjustments were made and once again distributed to stakeholders.

On 11 September 2002 the second draft of the qualifications was presented and discussed with a large representative group of stakeholders that included both providers and practitioners at the Conference of the Joint Universities' Committee for Social Work (JUC) in Potchefstroom. The Co-ordinator of NSB 09 attended the presentation to clarify SAQA issues. The critical issues that the SGB had had to contend with and those raised by stakeholders were discussed openly and recommendations agreed upon. Shortly after the Conference, the SGB met to consider all relevant issues raised at the JUC meeting and finalised the qualifications accordingly. 


\section{Submission of qualifications}

The SGB for Social Work developed five qualifications for submission to NSB 09 and SAQA for registration on the National Qualifications Framework (NQF). These included the FET Certificate in Social Auxiliary Work, the Bachelor of Social Work (B SW), Structured Master of Social Work (SM SW), Research Master of Social Work (RM SW), and Doctor of Social Work (PhD (SW)).

\section{FIRST SUBMISSION}

A number of delegates from the SGB met with NSB 09's Subcommittee on Standards and Qualifications on 17 October 2002 to discuss the five submitted qualifications. Of all the submissions, only the doctoral qualification was approved by the NSB and it later appeared in the Government Gazette of 28 October 2002 for comments.

Following the NSB meeting, a meeting was held with the Director of Standards Setting and Development at SAQA on 12 November 2002 regarding certain issues raised by NSB 09 and SAQA that the SGB wished to clarify further. Flowing from these two meetings, the brief of the SGB was to attend to the following recommendations with regard to the four outstanding qualifications:

- Include purpose statements for the electives of both the B SW and FET Certificate in Social Auxiliary Work qualifications and give an indication of the required combination of electives for these two qualifications;

- $\quad$ Revisit the NQF exit levels for both the B SW qualification and the FET Certificate in Social Auxiliary Work;

- Elaborate on the articulation of the B SW qualification with other social service professions, once professional boards have been established under the SACSSP and their qualifications developed;

- Rename the Research and Structured Master qualifications to indicate the difference more clearly;

- Review the purpose and learning outcomes of the Structured Master qualification to highlight more strongly the specialised field of this qualification;

- Attach a list of the names and organisations that were included in the consultation process;

- Provide the NQF computer codes (identification numbers) of the fundamental learning programmes in both the FET Certificate and B SW qualifications.

\section{Second submission}

The revised qualifications were submitted to NSB 09 in November 2002 and an SGB delegation presented the amendments to NSB 09's Subcommittee on Standards and Qualifications on 2 December 2002. At the plenary meeting of the NSB all the amendments were approved and recommended for registration on the NQF. Since then the FET Certificate in Social Auxiliary Work and the Bachelor of Social Work qualifications have been published in the Government Gazette, giving a 30-day comment period. Publication of the two Masters qualifications is awaited.

Once the comments have been dealt with by the SGB and the NSB, the SGB anticipates that the qualifications will be finally approved by SAQA and incorporated into the NQF by June 2003. 


\section{SOCIAL WORK QUALIFICATIONS}

The content of the five (5) social work qualifications approved to be registered with the NQF by the NSB needs to be contexutalised against the required SAQA format for qualifications (SAQA, 2000a:9). This necessitates a clarification of various concepts relevant to the designed qualifications, which will be briefly discussed (see SAQA Regulations, 1998a).

\section{Qualification}

A qualification is awarded when a learner achieves the required number and range of credits at a specific NQF level (SAQA Act, 1995:2). A qualification may be a certificate, diploma or degree and must have a planned combination of learning outcomes with a defined purpose, designed to provide qualifying learners with applied competence and a basis for further learning (SAQA, 2000a:41). It must also comply with the required number of credits set by SAQA.

In terms of the NQF, the name of a registered qualification must be the same throughout the country; irrespective of which institution is the provider.

Certain requirements prevail in order to ensure national standards. One example is that the Social Auxiliary Work Certificate has to include the acronym FET (Further Education and Training) as it is on NQF Level 4. A four-year professional degree such as Social Work is on NQF Level 7 and does not include the word "Honours", but it is equivalent to a Bachelors degree with Honours, being on the same NQF Level.

\section{Whole Qualifications versus Unit Standards}

SAQA permits two different routes for the registration of learning with the NQF and both have prescribed formats. These are known as "whole qualifications" and "unit standards".

The contents of a whole qualification indicate what qualifying learners will be able to do once they qualify (their competencies at the exit level). It also contains the criteria for assessment that ensure the learner has acquired the competencies through the learning programme. This means that there is a defined purpose(s) and a planned combination of learning outcomes intended to provide qualifying learners with applied competencies and a basis for further learning (SAQA, 2000c:41). A qualification, therefore, needs to have specific purposes that are embedded in the rationale for the qualification. The whole qualification basically sets out the skeleton for the learning programme and lays down the principles. It is then up to providers to develop the detailed curriculum by means of which learners will achieve the given competencies.

Unit standards, on the other hand, refer to specific statements of desired education and training outcomes (specific outcomes) and their associated assessment criteria (SAQA, 2000c:37). Each unit standard is registered as such with the NQF and may be as little as 2 credits. Unit standards mean that the learning programme is broken down into numerous end-statements with specific outcomes and assessment criteria for each competence. A unit standard is one of the building blocks for possible qualifications.

On the advice of a consultant, which was supported by SAQA personnel, the SGB initially began generating Unit Standards for the Bachelors qualification in Social Work. Considerable time and effort was spent on this route and many unit standards were developed in the process.

Although there are advantages to developing unit standards - for example, they provide clearer prescriptions for curriculum design - the SGB decided rather to take the "whole qualification" route. It is also relevant to note that qualifications based on unit standards or on whole qualifications are considered to be equally valid expressions of outcomes-based education 
(Department of Education, 2002:iv). The SGB's decision was based on the realisation that the generation of a whole qualification was essential to ensure holistic, coherent learning and lessen the possibility of being too prescriptive in respect of curriculum design. Nevertheless, the time spent on developing unit standards was not wasted as this process informed the social work qualifications and built the capacities of SGB members.

Qualifications are offered by a "provider", which is a term used by SAQA to refer to institutions/bodies that provide learning programmes focused on the achievement of specified NQF qualifications and standards. Providers, such as universities and technikons, also manage the assessment of learning achievements (SAQA Regulations 1998b:2). Providers must be registered with the relevant ETQA (Education and Training Quality Assurance Body) for the specific qualification. All education and training providers will be expected to offer learning programmes that comply with the standards of the social work qualifications. The SACSSP, in partnership with the Council on Higher Education, will be the ETQA for Social Work qualifications. In terms of Social Auxiliary Work qualifications, the Council, in partnership with the HWSETA, will be the ETQA.

\section{Fields}

Fields of learning are used as an organising mechanism for the NQF. SAQA established one National Standards Body for each of the 12 identified fields. Social Work falls under NSB 09 Health Sciences and Social Services and its sub-fields Preventive Health, Promotive Health and Development Services, Curative Health, and Rehabilitative Services.

These sub-fields are based on the World Health Organisation's definition of "health", which encompasses total health. The SGB is not in favour of this sub-field division and has requested NSB 09 to consider changing these sub-fields in order to reflect social welfare more independently from health.

\section{NQF levels}

Until the New Academic Policy (Council on Higher Education (CHE), 2001:49) has been approved, the Further Education and Training band (FET) is set at NQF Levels 2 to 4 and the Higher Education and Training band (HET) at NQF Levels 5 to 8 (SAQA, 2000b:23).

\section{Credit system}

A "credit" defines the value assigned by SAQA to 10 notional hours of learning. One (1) credit equals ten (10) notional hours of learning (SAQA, 2000b: 23). "Notional hours of learning" refers to the learning time that it takes an average learner to meet the defined outcomes. It includes contact time, time spent in structured learning in the workplace as well as individual learning.

SAQA's guidelines for the number of credits are 480 credits for a four-year professional qualification; 120 to 240 credits for a Masters degree; and 240 to 360 credits for a Doctoral degree.

In Social Work the amount of practical work adds considerably to the number of credits. Credits were thoroughly debated and carefully calculated by the SGB according to the requirements in terms of the depth of knowledge, understanding, insight and practice. However, the credits allocated to the qualification are considered to be the minimum and providers may add to this number. 


\section{Fundamental, Core and Elective Learning and Credits}

Credits are divided into Fundamental, Core and Elective Learning (Hallendorf et al., 2000:13; SAQA Regulations, 1998b:3-4).

Fundamental learning refers to that learning which forms the grounding or basis needed to undertake the education, training or further learning required to obtain a qualification. It generally refers to language and numeracy skills and is prescribed by SAQA according to specific NQF levels.

Core Learning refers to the learning that is essential for the qualification and means the compulsory learning required.

Elective Learning refers to a selection of additional credits at the specified level of the NQF from which learners may make a choice to ensure that the purpose of the qualification is achieved.

\section{Issue date and review date}

The issue date is the date the qualification/standard is registered with the NQF by SAQA. The review date refers to the period of time for which the qualification will be operational and before which a review and re-registration must take place. Currently the review period is 3 years, but applications for re-registration must be submitted in the first half of the third year of registration.

\section{Learning assumed to be in place}

Learning assumed to be in place must capture and make known the knowledge and skills that may reasonably be assumed to be in place before a learner enters a learning programme (SAQA 2000b: 24).

\section{Exit-level outcomes}

Outcomes state the knowledge, skills and values that a qualifying learner will have achieved at the point of leaving the learning programme leading to a qualification.

The exit level for the core modules of the FET Certificate in Social Auxiliary Work is on NQF Level 4, whilst the electives may indicate Levels 4 and 5 since Level 5 starts linking learning to a higher level. This qualification was approved by the HWSETA as a learnership ${ }^{2}$ in 2002 and awaits final registration by the Department of Labour. Once it has been registered, this will mean that both the learner and the provider may apply for funding for the learning process.

The exit level for the core outcomes of the Bachelor of Social Work is on NQF Level 7, whilst the exit levels for electives are reflected on Levels 5 and 6, respectively. In the current education system NQF Level 7 refers to the fourth year of study, whilst Levels 5 and 6 refer to the first, second and third years of study.

\section{Associated assessment criteria}

Each exit-level outcome has a number of associated assessment criteria that comprise a set of statements to guide the development of particular assessment tasks and tools. They should be viewed holistically as is the case with Outcomes.

\footnotetext{
2 A learnership refers to structured learning that includes practical work experience of a specialised nature and duration, leading to a qualification registered by SAQA and related to an occupation (Ministry of Education, 1998b:20); Ministry of Education (1998c:4). A learnership must be registered, as such, through a SETA with the Department of Labour. There are always 3 components present, namely a learner, an employer and a provider.
} 


\section{Critical cross-field outcomes}

A qualification must include the critical cross-field outcomes adopted by SAQA. These outcomes describe the qualities that the NQF identifies for the total development of learners within the education and training system, regardless of the specific area or content of learning. In other words, these are the outcomes that are deemed critical for the development of the capacity for lifelong learning and should guide policy makers, curriculum designers, facilitators of learning and learners themselves (SAQA, 2000b:18).

\section{International comparability}

Qualifications need to indicate their comparability in terms of similar qualifications in the international arena.

\section{Integrated assessment}

Qualifications should also indicate a variety of assessment techniques that will be used in an integrated manner to ensure that exit outcomes and critical cross-field outcomes are indeed achieved. Applied competencies should be demonstrated and a range of both formative and summative assessments should be used (SAQA Regulations, 1998a:4).

\section{Articulation possibilities}

In line with the NQF's objectives concerning an integrated framework and promoting access and progression, a qualification's generic and/or specific articulation possibilities must be indicated. Generic possibilities refer to the achievement of the qualification opening up possibilities for further learning or credit recognition. Specific possibilities refer to agreements that grant recognition of credits from one qualification to another, or part of another, both vertically and horizontally.

\section{Criteria for registration of assessors}

The minimum basic requirements for assessors of theoretical and practical learning need to be reflected in all qualifications.

\section{Moderation}

Moderation means the process that ensures that the assessment of the given outcomes is fair, reliable and valid (Ministry of Education, 1998a:4). Moderation cannot be undertaken by a provider's internal assessors, but must be undertaken by external sources.

Within this framework of requirements, the five qualifications will next be discussed by referring only to a few key components of the qualifications, i.e. exit levels, credits, purpose, learning assumed to be in place, articulation possibilities, criteria for assessors and exit-level outcomes as reflected in Tables 1 - 4. The full qualifications may be obtained from the Government Printer or transmitted electronically by the office of the SACSSP.

Given the ethical parameters of social work education, training and practice, all learners must be registered with the SACSSP as student social workers or pupil social auxiliary workers in terms of sections 17 and 18 respectively, of the Social Service Professions Act, 1978. 
TABLE 1

SOCIAL WORK DEGREES

\begin{tabular}{|c|c|c|c|c|}
\hline & Bachelor in Social Work & Structured Masters & Research Masters & Ph. D \\
\hline $\begin{array}{l}\text { NQF } \\
\text { Level }\end{array}$ & 7 & 8 & 8 & $8+$ \\
\hline Credits & 510 & 180 & 180 & 360 \\
\hline Purpose & $\begin{array}{l}\text { The purpose of this pro- } \\
\text { fessional 4-year qualification } \\
\text { is to equip learners with - } \\
\text { - Skills to challenge } \\
\text { structural sources of } \\
\text { poverty, inequality, } \\
\text { oppression, discrim- } \\
\text { ination and exclusion } \\
\text { - Knowledge and under- } \\
\text { standing of human } \\
\text { behaviour and social } \\
\text { systems and the skills to } \\
\text { intervene at the points } \\
\text { where people interact } \\
\text { with their environments } \\
\text { in order to promote } \\
\text { social well-being } \\
\text { The ability and compe- } \\
\text { tence to assist and } \\
\text { empower individuals, } \\
\text { families, groups, organi- } \\
\text { sations and communities } \\
\text { to enhance their social } \\
\text { functioning and their } \\
\text { problem-solving } \\
\text { capacities } \\
\text { The ability to promote, } \\
\text { restore, maintain and } \\
\text { enhance the functioning } \\
\text { of individuals, families, } \\
\text { groups and communities } \\
\text { by enabling them to ac- } \\
\text { complish tasks, prevent } \\
\text { and alleviate distress } \\
\text { and use resources ef- } \\
\text { fectively An understanding of } \\
\text { and the ability to de- } \\
\text { monstrate social work } \\
\text { values and the principles } \\
\text { of human rights and } \\
\text { social justice while } \\
\text { interacting with and } \\
\text { assisting the range of } \\
\text { human diversity }\end{array}$ & $\begin{array}{l}\text { The purpose of this qua- } \\
\text { lification is to provide } \\
\text { qualifiers with - } \\
\text { - Advanced, in-depth } \\
\text { knowledge of a spe- } \\
\text { cific field of social } \\
\text { work and social } \\
\text { welfare } \\
\text { The competencies to } \\
\text { effectively, critically } \\
\text { and systematically } \\
\text { access, analyse, } \\
\text { process, transform } \\
\text { and evaluate existing } \\
\text { knowledge in the } \\
\text { specific field } \\
\text { The ability to prac- } \\
\text { tically apply ad- } \\
\text { vanced professional } \\
\text { skills in the chosen } \\
\text { field } \\
\text { The knowledge and } \\
\text { skills to engage in } \\
\text { independent social } \\
\text { work research and to } \\
\text { produce a report } \\
\text { according to appro- } \\
\text { priate research me- } \\
\text { thodology in the } \\
\text { chosen field }\end{array}$ & $\begin{array}{l}\text { The purpose of this } \\
\text { qualification is to } \\
\text { provide qualifiers with } \\
\text { - } \\
\text { Advanced re- } \\
\text { search skills in a } \\
\text { chosen field of } \\
\text { social work } \\
\text { The competencies } \\
\text { to access, analyse, } \\
\text { process, transform } \\
\text { and critically eva- } \\
\text { luate existing } \\
\text { knowledge in } \\
\text { order to achieve } \\
\text { an integrated } \\
\text { synthesis of the } \\
\text { research field } \\
\text { The knowledge } \\
\text { and skills to en- } \\
\text { gage in in-depen- } \\
\text { dent social work } \\
\text { re-search, selec- } \\
\text { ting from a range } \\
\text { of appro-priate re- } \\
\text { search designs, } \\
\text { technologies, and } \\
\text { methods a an the } \\
\text { techniques in } \\
\text { chosen focus area } \\
\text { of social work } \\
\text { The ability to } \\
\text { produce and } \\
\text { communicate the } \\
\text { research findings }\end{array}$ & $\begin{array}{l}\text { This is a postgraduate } \\
\text { PhD qualification that is } \\
\text { aimed at creating the } \\
\text { opportunity for candi- } \\
\text { dates to engage in highly } \\
\text { advanced and specialised } \\
\text { academic or professional } \\
\text { study of and research } \\
\text { into an aspect of social } \\
\text { work and social welfare } \\
\text { services. } \\
\text { The degree will be con- } \\
\text { ferred only on those can- } \\
\text { didates who have demon- } \\
\text { strated the capacity for } \\
\text { independent thinking and } \\
\text { sustained original re- } \\
\text { search that makes a con- } \\
\text { tribution to the develop- } \\
\text { ment of well-grounded } \\
\text { new knowledge in the } \\
\text { field of social work. }\end{array}$ \\
\hline
\end{tabular}




\begin{tabular}{|c|c|c|c|c|}
\hline & Bachelor in Social Work & Structured Masters & Research Masters & Ph. D \\
\hline $\begin{array}{l}\text { NQF } \\
\text { Level }\end{array}$ & 7 & 8 & 8 & $8+$ \\
\hline \multirow[t]{2}{*}{ Credits } & 510 & 180 & 180 & 360 \\
\hline & 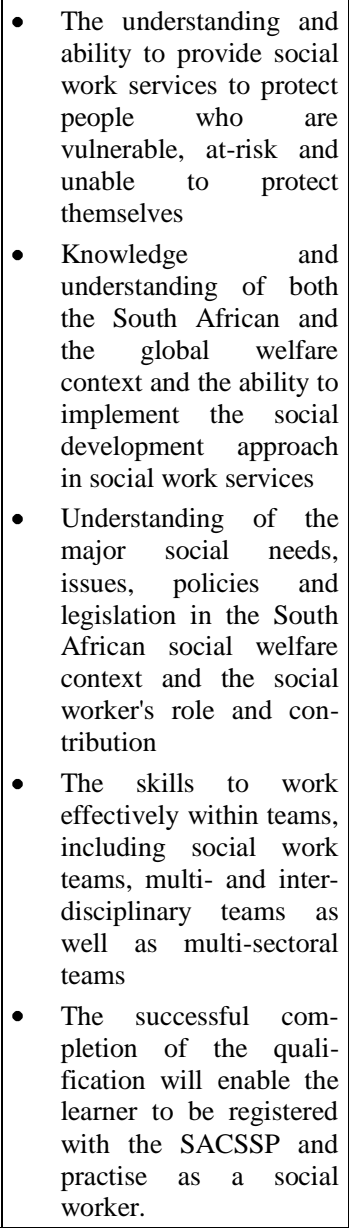 & & & \\
\hline $\begin{array}{l}\text { Learning } \\
\text { in place }\end{array}$ & $\begin{array}{l}\text { Learners must have the } \\
\text { following skills } \\
\text { equivalent to NQF Level } \\
\text { 4: Reading, writing, } \\
\text { listening and speaking in } \\
\text { English as at least } 80 \% \\
\text { of all textbooks and } \\
\text { documentation are in } \\
\text { English } \\
\text { The ability to undertake } \\
\text { independent learning. }\end{array}$ & & & \\
\hline
\end{tabular}




\begin{tabular}{|c|c|c|c|c|}
\hline & Bachelor in Social Work & Structured Masters & Research Masters & Ph. D \\
\hline $\begin{array}{l}\text { NQF } \\
\text { Level }\end{array}$ & 7 & 8 & 8 & $8+$ \\
\hline \multirow[t]{2}{*}{ Credits } & 510 & 180 & 180 & 360 \\
\hline & $\begin{array}{l}\text { - A typical applicant will } \\
\text { have a NQF Level } 4 \\
\text { qualification, equivalent } \\
\text { to matriculation with } \\
\text { full exemption or an } \\
\text { appropriate access-route } \\
\text { qualification approved } \\
\text { by the service provider. }\end{array}$ & $\begin{array}{l}\text { Candidates must have an } \\
\text { NQF Level } 7 \text { qualification } \\
\text { in Social Work and be } \\
\text { registered with the } \\
\text { SACSSP as a social } \\
\text { worker. } \\
\text { Applicants without the } \\
\text { above, who can } \\
\text { demonstrate, to the } \\
\text { satisfaction of the } \\
\text { provider, that they have } \\
\text { an appropriate, related } \\
\text { qualification, experiential } \\
\text { or work-based learning, } \\
\text { which has taken them to } \\
\text { the equivalent of an NQF } \\
\text { Level } 7 \text { Social Work } \\
\text { qualification, may be } \\
\text { considered for admission } \\
\text { into this social work } \\
\text { programme. }\end{array}$ & $\begin{array}{l}\text { Candidates must have } \\
\text { an NQF Level } 7 \\
\text { qualification in Social } \\
\text { Work and be } \\
\text { registered with the } \\
\text { SACSSP as a social } \\
\text { worker. } \\
\text { Applicants without the } \\
\text { above, who can } \\
\text { demonstrate, to the } \\
\text { provider's satisfaction, } \\
\text { that they have an } \\
\text { appropriate, related } \\
\text { qualification, } \\
\text { experiential or work- } \\
\text { based learning, which } \\
\text { has taken them to the } \\
\text { equivalent of an NQF } \\
\text { Level } 7 \text { Social Work } \\
\text { qualification, may be } \\
\text { considered for } \\
\text { admission. }\end{array}$ & $\begin{array}{l}\text { Candidates must have an } \\
\text { NQF Level } \\
\text { qualification in Social } \\
\text { Work and be registered } \\
\text { with the SACSSP as a } \\
\text { social worker. } \\
\text { In terms of RPL, } \\
\text { applicants outside of the } \\
\text { admissions criteria, who } \\
\text { can demonstrate to the } \\
\text { provider's satisfaction } \\
\text { that they have an } \\
\text { appropriate, related } \\
\text { qualification, experiential } \\
\text { or work-based learning, } \\
\text { which has taken them to } \\
\text { the equivalent of an NQF } \\
\text { Level } 8 \text { Social Work } \\
\text { qualification, may be } \\
\text { considered for admission. }\end{array}$ \\
\hline $\begin{array}{l}\text { Articu- } \\
\text { lation }\end{array}$ & $\begin{array}{l}\text { Learners with an NQF Level } \\
7 \text { Social Work qualification } \\
\text { may proceed to a Masters } \\
\text { programme in Social Work } \\
\text { or further learning } \\
\text { programmes in Social Work } \\
\text { and other related fields, } \\
\text { depending on the electives } \\
\text { chosen and the entry } \\
\text { requirements of such pro- } \\
\text { grammes. } \\
\text { Depending on the combi- } \\
\text { nation of credits taken at } \\
\text { NQF Levels } 5 \text { and } 6 \text {, } \\
\text { horizontal articulation will } \\
\text { be possible with other social } \\
\text { service professions pro- } \\
\text { grammes when they become } \\
\text { available as well as other } \\
\text { disciplines. } \\
\text { A learner who does not } \\
\text { complete the Social Work } \\
\text { qualification may be } \\
\text { assessed by a registered } \\
\text { provider for the recognition } \\
\text { of credits towards obtaining } \\
\text { the FET Certificate in Social } \\
\text { Auxiliary Work. }\end{array}$ & $\begin{array}{l}\text { Qualifiers with an NQF } \\
\text { Level } 8 \text { Social Work } \\
\text { qualification may proceed } \\
\text { to a Doctors programme } \\
\text { in Social Work. } \\
\text { Articulation possibilities } \\
\text { exist both within the } \\
\text { tertiary institution } \\
\text { offering the Social Work } \\
\text { programme and across } \\
\text { tertiary institutions. }\end{array}$ & $\begin{array}{l}\text { Qualifiers with an } \\
\text { NQF Level } 8 \text { Social } \\
\text { Work qualification } \\
\text { may proceed to a } \\
\text { Doctoral programme } \\
\text { in Social Work (NQF } \\
\text { Level 8). } \\
\text { Articulation } \\
\text { possibilities exist both } \\
\text { within the tertiary in- } \\
\text { stitution offering the } \\
\text { Social Work program- } \\
\text { me and across tertiary } \\
\text { institutions. }\end{array}$ & $\begin{array}{l}\text { Articulation possibilities } \\
\text { exist both within the } \\
\text { tertiary institution } \\
\text { offering the Social Work } \\
\text { programme and across } \\
\text { tertiary institutions. The } \\
\text { possibility of horizontal } \\
\text { articulation in the form } \\
\text { of a related Doctor's } \\
\text { Degree, is available. }\end{array}$ \\
\hline
\end{tabular}




\begin{tabular}{|c|c|c|c|c|}
\hline & Bachelor in Social Work & Structured Masters & Research Masters & Ph. D \\
\hline $\begin{array}{l}\text { NQF } \\
\text { Level }\end{array}$ & 7 & 8 & 8 & $8+$ \\
\hline Credits & 510 & 180 & 180 & 360 \\
\hline $\begin{array}{l}\text { Criteria } \\
\text { for } \\
\text { Assessors } \\
\text { (The mini- } \\
\text { mum basic } \\
\text { require- } \\
\text { ments for } \\
\text { assessors) }\end{array}$ & $\begin{array}{l}\text { For theoretical and practical } \\
\text { learning: } \\
\text { - Registration with the } \\
\text { SACSSP } \\
\text { - At least a professional } \\
\text { degree in Social Work } \\
\text { (NQF Level 7) } \\
\text { A minimum of } 5 \text { years } \\
\text { appropriate experience. } \\
\text { Registration as an asses- } \\
\text { sor with the relevant } \\
\text { ETQA. }\end{array}$ & $\begin{array}{l}\text { Internal assessors must be } \\
\text { registered with the } \\
\text { SACSSP and have at least } \\
\text { a Masters degree in Social } \\
\text { Work (NQF Level 8). } \\
\text { External assessors must } \\
\text { have an appropriate quali- } \\
\text { fication and/or appro- } \\
\text { priate experience in the } \\
\text { chosen focus area. } \\
\text { Assessors must be regi- } \\
\text { stered with the relevant } \\
\text { ETQA. }\end{array}$ & 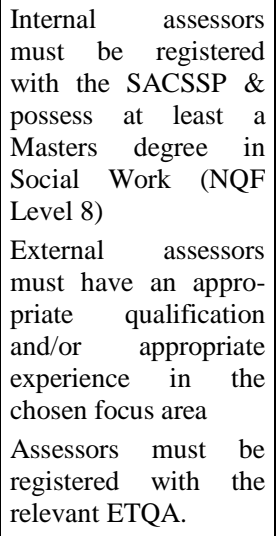 & $\begin{array}{l}\text { Internal assessors must } \\
\text { be registered with the } \\
\text { SACSSP and have at } \\
\text { least a Masters degree in } \\
\text { Social Work (NQF Level } \\
8 \text { ) } \\
\text { External assessors must } \\
\text { have an appropriate qua- } \\
\text { lification and/ or appro- } \\
\text { priate experience in the } \\
\text { chosen focus area } \\
\text { Assessors must be regi- } \\
\text { stered with the relevant } \\
\text { ETQA. }\end{array}$ \\
\hline
\end{tabular}

TABLE 2

SOCIAL WORK (B SW) NQF LEVEL 7

\begin{tabular}{|c|c|}
\hline Component & Exit-Level Outcomes \\
\hline $\begin{array}{l}\text { Fundamental } \\
(10 \text { credits })\end{array}$ & $\begin{array}{l}\text { Bridging Programmes/ Programmes in } 1 \text { or more of the following: } \\
\text { Communication Studies } \\
\text { Study Methodology/ Academic Skills } \\
\text { Computer Literacy } \\
\text { Information Technology }\end{array}$ \\
\hline $\begin{array}{l}\text { Core } \\
\text { (320 credits) }\end{array}$ & $\begin{array}{l}\text { 1. Develop and maintain professional social work relationships with client systems }{ }^{3} \\
\text { 2. Assess client systems' social functioning } \\
\text { 3. Plan and implement appropriate social work intervention strategies \& techniques at micro, } \\
\text { mezzo \& macro levels } \\
\text { 4. Access and utilise resources appropriate to client systems' needs and strengths } \\
\text { 5. Produce and maintain records of social work interventions, processes and outcomes } \\
\text { 6. Evaluate the outcomes of social work intervention strategies, techniques and processes } \\
\text { 7. Terminate social work intervention } \\
\text { 8. Negotiate and utilise contracts during social work intervention } \\
\text { 9. Demonstrate social work values while interacting with human diversity } \\
\text { 10. Appraise and implement the ethical principles and values of social work } \\
\text { 11. Use, plan and execute social work research } \\
\text { 12. Work effectively with social workers and members of inter-sectoral and multi- and/or } \\
\text { inter-disciplinary teams in social service delivery } \\
\text { 13. Identify, select and implement various techniques, methods and means of raising } \\
\text { awareness, developing critical consciousness about the structural forces of oppression, } \\
\text { exclusion and disempowerment, and use such awareness to engage people as change } \\
\text { agents }\end{array}$ \\
\hline
\end{tabular}




\begin{tabular}{|c|c|}
\hline Component & Exit-Level Outcomes \\
\hline & $\begin{array}{l}\text { 14. Analyse human behaviour with regard to the intersections of race, class, culture, ethnicity, } \\
\text { gender, differential abilities and sexual orientation } \\
\text { 15. Critically appraise social welfare and social work from a global, regional (African) and } \\
\text { national perspective. Critically appraise the current status and position of the social work } \\
\text { profession within the South African welfare context } \\
\text { 16. Apply and uphold the basic values and principles enshrined in the Bill of Rights in the SA } \\
\text { Constitution in relation to social work service delivery } \\
\text { 17. Elucidate national, provincial and local governance structures, and the general laws and } \\
\text { charters governing social welfare policy and social work services in South Africa } \\
\text { 18. Demonstrate understanding of how social policies and legislation on social issues impact } \\
\text { on these issues and how to use legislation ethically and accountably in order to protect and } \\
\text { improve the quality of life of client systems from a social work perspective } \\
\text { 19. Demonstrate understanding of how social welfare policy and legislation are developed and } \\
\text { influenced } \\
\text { 20. Demonstrate understanding of the roles, functions, knowledge and skills for effective } \\
\text { social work supervision and consultation } \\
\text { 21. Demonstrate understanding of the roles, functions, principles and characteristics of } \\
\text { management and administration within social service delivery } \\
\text { 22. Formulate a business plan for the funding of social services } \\
\text { 23. Identify the influence of the relationship between socio-political and economic factors on } \\
\text { social services } \\
\text { 24. Demonstrate understanding of the roles and functions of the social worker within relevant } \\
\text { statutory frameworks } \\
\text { 25. Identify how social security is used optimally for the benefit of client systems } \\
\text { 26. Identify the purpose, functions and principles of social work within the social development } \\
\text { paradigm }\end{array}$ \\
\hline $\begin{array}{l}\text { Electives } \\
\text { (180 credits) }\end{array}$ & $\begin{array}{l}\text { From the following electives credits to the value of } 100 \text { must be selected from the Humanities } \\
\text { \& Social Sciences. At least } 110 \text { of the total number of } 180 \text { credits must be completed at NQF } \\
\text { Level } 6 \text {. } \\
\text { Humanities and Social Sciences } \\
\text { Understanding of human nature, thinking, characteristics, relations, the structure of society and } \\
\text { the activities of its members in order to respond appropriately to people in various social } \\
\text { contexts. For example, but not limited to: Communication, Criminology, Human Resource } \\
\text { Management, International Relations, Languages (South African), Philosophy, Political } \\
\text { Science, Psychology, Social Anthropology, Sociology, Religious Studies. } \\
\text { Economics } \\
\text { Basic understanding of economics, business management, resource management and } \\
\text { entrepreneurship that facilitates sustainable poverty alleviation initiatives and interventions. } \\
\text { Law } \\
\text { Understanding of legal aspects including, but not limited to, introduction to the law, legal aid, } \\
\text { procedural law, legal status of a person, criminal law and punishment, matrimonial law, divorce } \\
\text { law, child and family law, law of persons. } \\
\text { Health Sciences } \\
\text { Understanding of health issues and their impact on the social functioning of individuals, } \\
\text { families, groups and communities. } \\
\text { Agricultural/ Environmental Studies } \\
\text { Understanding of the interaction between developmental initiatives, communities and the } \\
\text { environment. } \\
\text { Arts } \\
\text { Ability to use various art forms in an artistic, creative manner for preventive, promotive and } \\
\text { developmental purposes in social work interventions. }\end{array}$ \\
\hline
\end{tabular}




\section{TABLE 3 \\ EXIT-LEVEL OUTCOMES FOR POSTGRADUATE QUALIFICATIONS (NQF LEVELS 8 AND 8+)}

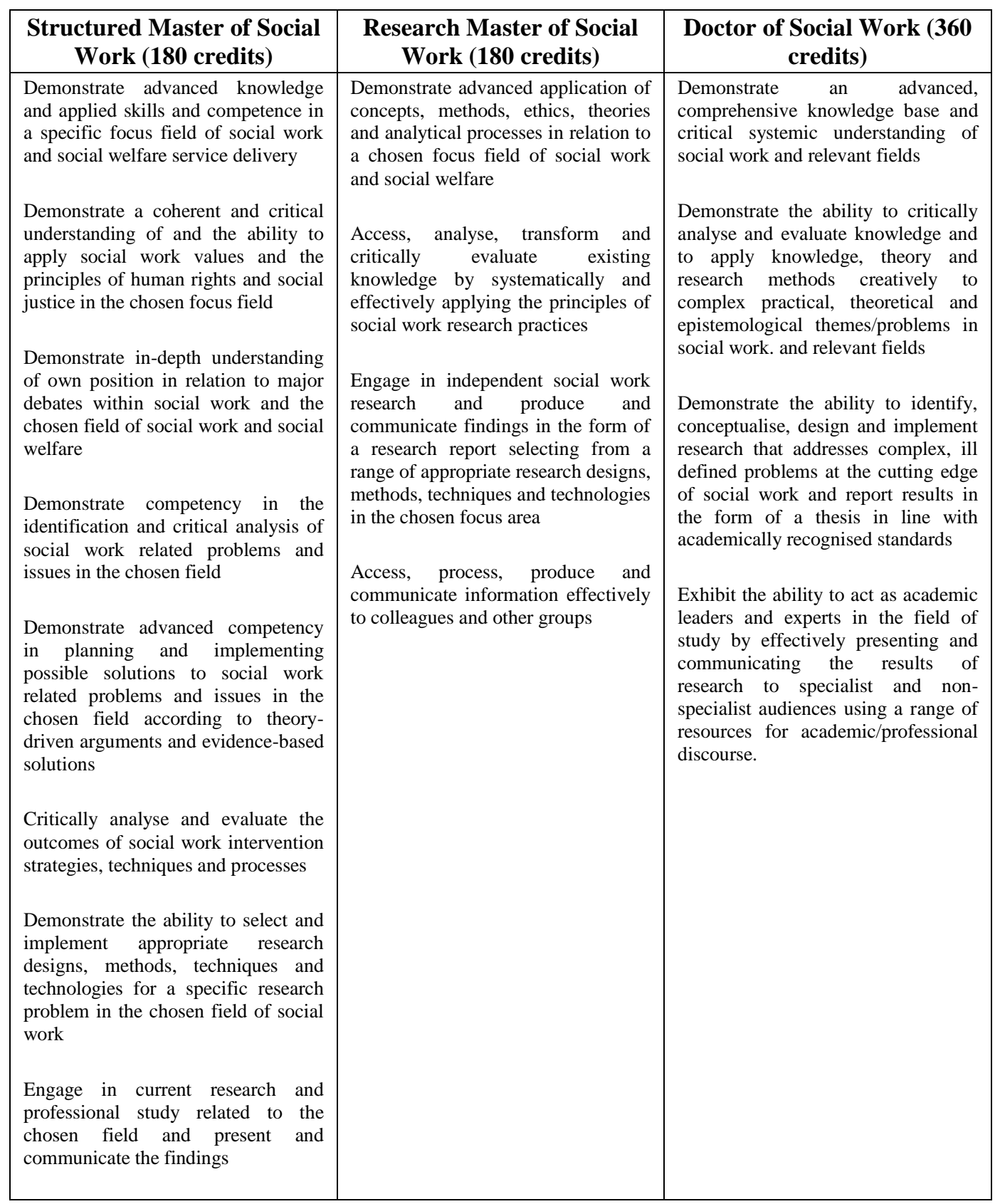


TABLE 4

FET CERTIFICATE IN SOCIAL AUXILIARY WORK

\begin{tabular}{|c|c|}
\hline \multicolumn{2}{|c|}{ MATRIX OF EXIT-LEVEL OUTCOMES } \\
\hline NQF Level & 4 \\
\hline Credits & 180 \\
\hline Purpose & $\begin{array}{l}\text { The purpose of the qualification is to equip qualifying learners with the following: } \\
\text { - Basic knowledge and understanding of the South African context within which social services } \\
\text { function and are delivered } \\
\text { Understanding of social development in terms of the needs, policies and the role of the social } \\
\text { auxiliary worker } \\
\text { Basic knowledge of human behaviour, relationship systems and social issues and the ability to } \\
\text { address social needs using appropriate social auxiliary work methods and techniques } \\
\text { The skills to work as a team member and as a provider of support services to the social work } \\
\text { team } \\
\text { The successful completion of the qualification will enable the learner to - } \\
\text { - register with the SA Council for Social Service Professions as a Social Auxiliary Worker in } \\
\text { terms of section } 18 \text { of the Social Service Professions Act, } 1978 \text { (Act } 110 \text { of 1978); and } \\
\text { - continue learning \& gain access, for example to the Bachelor of Social Work (NQF Level 7) } \\
\text { qualification. }\end{array}$ \\
\hline $\begin{array}{l}\text { Learning in } \\
\text { place }\end{array}$ & $\begin{array}{l}\text { In order to gain access to this qualification a learner must possess at least a Grade } 10 \text { or equivalent } \\
\text { certificate or an NQF Level } 3 \text { qualification. } \\
\text { Learners registering for this qualification must have the following skills: } \\
\text { - Reading, writing, listening \& speaking in English, equivalent to NQF Level 3, as at least } 80 \% \\
\text { of the textbooks \& documentation are in English. } \\
\text { - The ability to undertake independent learning. } \\
\text { Any learner wishing to be assessed for the Recognition of Prior Learning may do so, according to } \\
\text { recognised procedures. } \\
\text { Learners not in possession of such qualifications may access a Bridging programme and if } \\
\text { successful, they will be accepted as learners for the social auxiliary work qualification. }\end{array}$ \\
\hline Articulation & $\begin{array}{l}\text { This qualification provides access to the NQF Level } 7 \text { qualification in Social Work. } \\
\text { It may also provide access to and recognition by a wide range of social service qualifications, when } \\
\text { they are available, such as Child and Youth Care, Youth Work, Community Development and } \\
\text { Probation Work. }\end{array}$ \\
\hline $\begin{array}{l}\text { Criteria for } \\
\text { Assessors }\end{array}$ & $\begin{array}{l}\text { Assessors of theoretical and practical learning must meet the following criteria: } \\
\text { - } \quad \text { Be in possession of a Level } 7 \text { qualification in Social Work. } \\
\text { - } \quad \text { Be registered with the SACSSP as a Social Worker. } \\
\text { - } \quad \text { Have a minimum of } 5 \text { years practical social work experience. } \\
\text { - } \quad \text { Be registered as a qualified assessor by the relevant ETQA. }\end{array}$ \\
\hline $\begin{array}{l}\text { Fundamental } \\
\text { (56 credits) }\end{array}$ & $\begin{array}{l}\text { Literacy \& Communication skills } \\
\text { Mathematics } \\
\text { Second S A Language }\end{array}$ \\
\hline $\begin{array}{l}\text { Core } \\
\text { (116 credits) }\end{array}$ & $\begin{array}{l}\text { 1. Demonstrate basic understanding of the South African social welfare context, the policy and } \\
\text { practice of developmental social welfare services \& the role of the social auxiliary worker } \\
\text { within this context. } \\
\text { 2. Consistently reflect the values and principles contained in the Bill of Rights and the social } \\
\text { work profession's Code of Ethics in service delivery as a social auxiliary worker. } \\
\text { 3. Demonstrate a basic understanding of the South African judicial system and the legislation } \\
\text { governing and impacting on social auxiliary work and social work. } \\
\text { 4. Demonstrate a basic understanding of human behaviour, relationship systems and social }\end{array}$ \\
\hline
\end{tabular}




\begin{tabular}{|c|c|}
\hline & $\begin{array}{l}\text { issues. } \\
\text { 5. Implement appropriate social auxiliary work methods and techniques to address the social } \\
\text { needs of client systems. } \\
\text { 6. Use appropriate resources in service delivery to client systems. } \\
\text { 7. Work effectively with social workers and members of multi-sectoral teams in social service } \\
\text { delivery. } \\
\text { 8. Work effectively as a social auxiliary worker to address the special needs and problems } \\
\text { 9. Keep precise records and compile accurate reports on social needs and social auxiliary work } \\
\text { activities and file them appropriately. } \\
\text { 10. Provide an efficient research and administrative support service to the social worker. } \\
\text { 11. Demonstrate basic knowledge of financial matters related to social auxiliary work. } \\
\text { 12. Demonstrate self-awareness regarding personal capacities, attitudes and skills and a } \\
\text { willingness to develop them further under the supervision of a social worker. }\end{array}$ \\
\hline $\begin{array}{l}\text { Electives } \\
\text { ( } 8 \text { credits })\end{array}$ & $\begin{array}{l}\text { Basic understanding of the policies, legislation and organisational functioning as well as the ability, } \\
\text { within the team context, to respond as a social auxiliary worker in one of the following focus areas: } \\
\text { - } \quad \text { Child and Family Life } \\
\text { - } \quad \text { Child and Youth Care } \\
\text { - } \quad \text { Youth work } \\
\text { - } \quad \text { Disabilities } \\
\text { - } \quad \text { Drug abuse } \\
\text { - } \quad \text { Chronic illnesses } \\
\text { - } \quad \text { Mental Health } \\
\text { - } \quad \text { Older persons } \\
\text { - } \quad \text { Correctional services } \\
\text { - } \quad \text { Victim empowerment } \\
\text { - } \\
\text { - } \\
\text { Cife Skills }\end{array}$ \\
\hline
\end{tabular}

\section{PROCESS FORWARD}

With regard to the process forward, the priorities are as follows:

- Higher tertiary institutions will have to benchmark their current qualifications against the outcomes of the social work qualifications and submit them to the SGB for evaluation.

- The SGB will attend to its extended brief that has been authorised by NSB 09 to write diplomas for specialised Social Work qualifications.

- Planning for the process to be followed with providers for the Social Auxiliary Work qualification. These providers will be training institutions and social service/welfare organisations.

\section{CONCLUSION}

The Social Work profession has paved the way for other professions to submit their qualifications for registration on the NQF. By being proactive in registering Social Work qualifications in good time with the NQF, providers will have ample time to redesign their programmes and channel them through the processes for registration at SAQA by June 2006.

Although the registration of Social Work qualifications on the NQF is required by SAQA, it primarily signifies a unique achievement by the social work profession. It is an historical event for 
Social Work in South Africa that standardised qualifications are in place. From this basis the profession is posing a challenge to all the stakeholders who contributed to this process to continue to revise qualifications and standards for the social work profession in order to meet the demands of South African society.

\section{REFERENCES}

COUnCIL On Higher EDUCATION (CHE) 2001. A new Academic Policy for Programmes and Qualifications in Higher Education, Discussion Document, Pretoria.

DEPARTMENT OF EDUCATION (DoE) AND DEPARTMENT OF LABOUR (DoL) 2002. Report of the Study team on the Implementation of the National Qualifications Framework. Pretoria.

HALLENDORF, E; RICHARDSON, B \& WOOD, B 2000. Standards Winter Course. Johannesburg: The Learning Network (Pty) Ltd.

OLIVIER, C 1998. How to educate and train Outcomes-Based. Pretoria: JL van Schaik.

RSA MINISTRY OF EDUCATION 1995. South African Qualifications Authority Act, 1995 (Act 58 of 1995) Government Gazette, Vol. 364, No.16725 (4 October). Pretoria: Government Printer.

RSA MINISTRY OF EDUCATION 1998a. Regulations under the South African Qualifications Authority Act, 1995 (Act 58 of 1995) Government Gazette, Vol. 393. No. 18787 (28 March). Pretoria: Government Printer.

RSA MINISTRY OF EDUCATION 1998b. Regulations under the South African Qualifications Authority Act, 1995 (Act 58 of 1995) Government Gazette, Vol. 1127. No. 19231 (8 September). Pretoria: Government Printer.

RSA MINISTRY OF LABOUR 1998c. Skills Development Act, 1998. (Act 97 of 1998) Government Gazette, Vol. 401. No. 19420 (19420). Pretoria: Government Printer.

SAQA. 2000a. The National Qualifications Framework: An overview. Pretoria.

SAQA. 2000b. The National Qualifications Framework and Curriculum Development. Pretoria.

SAQA. 2000c. The National Qualifications Framework and Standards Setting. Pretoria.

SAQA. 2001. Public Notice by NSB 09, Health Sciences and Social Services, the Registration of an SGB for Social Work. Government Gazette, Vol. 430. No. 22221 (12 April). Pretoria: Government Printer. 